\title{
Analysis and Evaluation of the Impact of Railway Infrastructure Parameters Changes on "Rail Baltica" Project Implementation
}

\author{
Vytautas Palevičius*, Mantas Kaušylas \\ Department of Roads, Vilnius Gediminas Technical University, Vilnius, Lithuania
}

Received 26 February 2020; accepted 20 April 2020

\begin{abstract}
Rail Baltica" project is priority project No 27 "Rail Baltica" axis Warsaw-Kaunas-Riga-Tallinn-Helsinki, approved by Decision No 884/2004/EC of the European Parliament and of the Council of 29 April 2004 amending Decision No 1692/96/EC on Community guidelines for the development of the trans-European transport network (European Union, 2004). An article analyzes the changes in the main parameters of the $1435 \mathrm{~mm}$ gauge railway infrastructure during the whole period of the "Rail Baltica" project, determines their impact on the project implementation timeline, purposes and results, highlights basic parameters which need to be met during modernization. On this basis, the main criteria for the evaluation of Rail Baltica rail infrastructure were selected. An expert survey was conducted to evaluate the criteria. The Kendall method was used to calculate the criteria weights. The article ends with a scientific discussion.
\end{abstract}

Keywords: "Rail Baltica" development, railway infrastructure, Kendall method.

\section{Introduction}

Initiation and planning of railway infrastructure modernization projects usually are fallowed by such constraints as insufficient financial resources, time shortage for project preparation and implementation, requirements from the infrastructure manager to avoid traffic brakes as much as possible, changes in technical requirements and parameters, emergence of new projects, which have influence for main project technical solutions (Han et al., 2009). It should be noted, that "Rail Baltica" project is not an exception regarding mentioned constraints as well.

First construction works of "Rail Baltica" $1435 \mathrm{~mm}$ railway line from Polish - Lithuanian state border till Kaunas were started on 2010 in Mockava - Šeštokai section. During construction works, which were finished on September $2011,7.5 \mathrm{~km}$ length of 1435/1520 mm gauntleted track were reconstructed accordingly.

Construction works of second section from Mockava till Polish-Lithuanian state border were started on May 2013 and were finished on October 2014. During construction works $13.2 \mathrm{~km}$ length of existing $1435 \mathrm{~mm}$ gauge railway track, as well as $1435 \mathrm{~mm}$ gauge and $1520 \mathrm{~mm}$ gauge tracks were reconstructed in Mockava station.

Construction works of $33 \mathrm{~km}$ length third section from Šeštokai till Marijampole were started on June 2013 and were finished on April 2015. During construction works was reconstructed an existing $1520 \mathrm{~mm}$ gauge railway track by constructing $1435 \mathrm{~mm}$ gauge track and $1520 \mathrm{~mm}$ gauge track on single embankment.

It should be noted that the same technical solution - reconstruction of existing $1520 \mathrm{~mm}$ gauge track by constructing of $1435 \mathrm{~mm}$ gauge track and $1520 \mathrm{~mm}$ gauge track on single embankment was used for fourth $33 \mathrm{~km}$ length Marijampolè - Kazlų Rūda section as well. Reconstruction works of this section were started on June 2013 and were finished on March 2015.

During reconstruction works of last Kazlų Rūda - Mauručiai, Mauručiai - Jiesia and Jiesia - Kaunas sections, which total length is $36 \mathrm{~km}$, two existing $1520 \mathrm{~mm}$ gauge tracks were reconstructed by constructing two $1520 \mathrm{~mm}$ gauge tracks and $1435 \mathrm{~mm}$ gauge track on single embankment.

All reconstruction works, in 2010-2015, from Polish - Lithuanian state border till Kaunas were followed by reconstruction of Šeštokai, Kalvarija, Marijampolè, Kazlų Rūda, Mauručiai, Jiesia and Kaunas stations. It should be noted that $1435 \mathrm{~mm}$ gauge railway line Polish - Lithuanian state border - Kaunas was constructed accordingly in Commission Decision No 2011/275/EU of 26 April 2011 concerning a technical specification for interoperability relating to the "infrastructure" subsystem of the trans-European conventional rail system indicated VII-M category railway line parameters: mixed traffic, $120 \mathrm{~km} / \mathrm{h}$ passenger train speed, $500 \mathrm{~m}$ train length, GA gauge structure and $22.5 \mathrm{t}$ axle load.

*Corresponding author. E-mail: vytautas.palevicius@vgtu.lt 
Such relatively low $120 \mathrm{~km} / \mathrm{h}$ speed parameter was used because of the project constraint - project financing timeline with significant time shortages for territorial planning, land acquisition, design and construction activities. Therefore, the decision to design and construct in the existing railway land plots was taken. Second reason was the lack of commonly agreed technical parameters as well as different development strategies between project partners.

It should be important to state that on 31 January 2017 Intergovernmental Agreement (hereinafter - Intergovernmental Agreement) was signed between the Government of the Republic of Latvia, the Government of the Republic of Estonia and the Government of the Republic of Lithuania On the Development of the Rail Baltic/Rail Baltica Railway Connection. It was agreed to ensure the completion and functionality of an effective fast conventional European gauge railway, built as a project of common interest according to the common technical parameters, for passengers and freight transport on a route as part of the TEN-T Network North Sea - Baltic Core Network Corridor.

It was agreed as well to construct new fast conventional double track electrified railway line with the maximum design speed of $240 \mathrm{~km} / \mathrm{h}$ and European standard gauge $(1435 \mathrm{~mm})$ on the route be complete in accordance with uniform technical parameters based on the Commission Regulation (EU) No 1299/2014 of 18 November 2014 on the technical specifications for interoperability relating to the "infrastructure" subsystem of the rail system in the European Union (hereinafter - INF TSI).

Accordingly with INF TSI, it was agreed to construct P2/F1 category railway line: mixed traffic, $25 \mathrm{AC} \mathrm{kV}$ electrified double track, $240 \mathrm{~km} / \mathrm{h}$ design speed for passenger trains, $120 \mathrm{~km} / \mathrm{h}$ design speed for freight trains, 740$1050 \mathrm{~m}$ freight train length, 200-400 passenger train length, GC gauge structure, $4.2 \mathrm{~m}$ distance between track centres and $22.5 \mathrm{t}$ axle load.

INF TSI parameters agreed to use for "Rail Baltica" project developments were updated on April 2018, when unified "Rail Baltica" Design Guidelines (hereinafter - RBDG) were approved. It was agreed to design and construct "Rail Baltica" railway lines accordingly to newly updated parameters: mixed traffic, $25 \mathrm{kV}$ AC electrified double track, $249 \mathrm{~km} / \mathrm{h}$ design speed for passenger trains, $120 \mathrm{~km} / \mathrm{h}$ design speed for freight trains, $1050 \mathrm{~m}$ freight train length, 400 passenger train length, GC gauge structure, $4.5 \mathrm{~m}$ distance between track centres and $25 \mathrm{t}$ axle load. It is important to note as well that structure gauge parameter GC was updated to structure gauge parameter SeC on 2020.

However, such significant changes in "Rail Baltica" project technical parameters induced the need to modernize existing or even to construct completely new "Rail Baltica" Polish/Lithuanian state border - Kaunas railway line. Therefore, to find optimal railway modernization alternative, several technical studies were prepared.

Thus, this article will try to solve main question: what basic parameters are needed to be met during modernization of the projects when insufficient financial resources and time shortage for project preparation and implementation exist?

\section{Rail Baltica development in Lithuania}

Accordingly, with Intergovernmental Agreement, Parties have agreed to ensure completion and functionality of the railway by 2025 in order to commence its operation by 2026. Therefore, it is planned to modernize according with the newest parameters an existing $1435 \mathrm{~mm}$ gauge Polish/Lithuanian border - Kaunas railway line (86.0 km length), as well as to develop and complete Kaunas railway node with Jiesia-Kaunas ( $8 \mathrm{~km}$ length), Kaunas-Palemonas (10 km length), Jiesia-Rokai (5 km length) and Rokai-Palemonas (8 km length) sections (Figure 1).

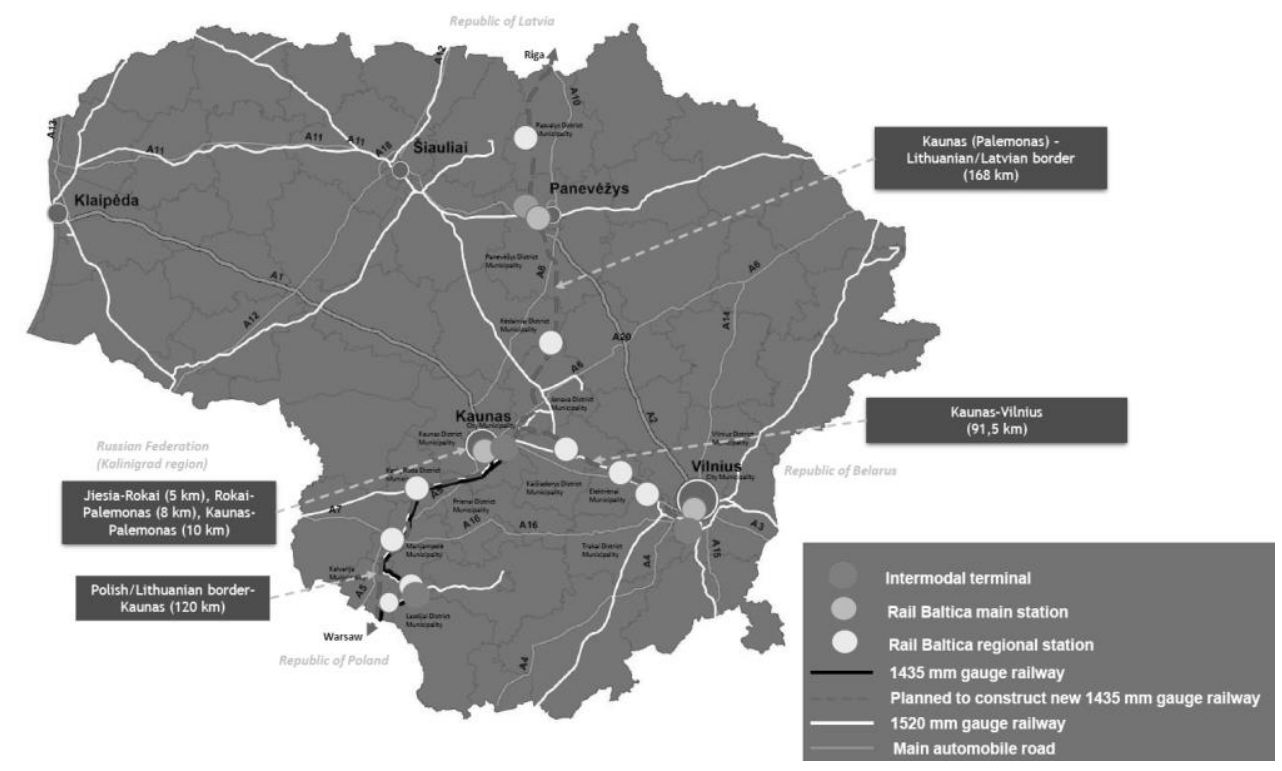

Figure 1. Rail Baltica development in Lithuania 
For the connection with Latvia it is foreseen to construct new railway line from Kaunas to Lithuanian/Latvian border (168 km length) and for Vilnius connection - to construct new railway line from Kaunas to Vilnius (91.5 km length). It is agreed to construct three international passenger stations in Kaunas, Vilnius and Panevėžys. For freight transportation new $1435 \mathrm{~mm}$ gauge freight yards with at least 8 tracks $1050 \mathrm{~m}$ useful length will be constructed in Kaunas and Vilnius, which will serve for Kaunas and Vilnius intermodal terminals. To ensure higher usage and effectiveness of the "Rail Baltica" infrastructure it is agreed to construct new regional stations, stops or halts along the new railway lines. For proper infrastructure maintenance new infrastructure maintenance facilities will be designed and constructed in Kaunas and Panevėžys areas, as well as infrastructure maintenance points will be created in Vilnius and Marijampolè.

An existing $1435 \mathrm{~mm}$ gauge railway line Polish/Lithuanian border - Kaunas, which is foreseen to be modernized, will be used as a regional line and will have the connections with the exiting station. The railway stations and their connections to the main line, such as Mockava, Šeštokai, Marijampole and Kazlų Rūda, which are under operation already, will be used for regional purposes (Figure 2).

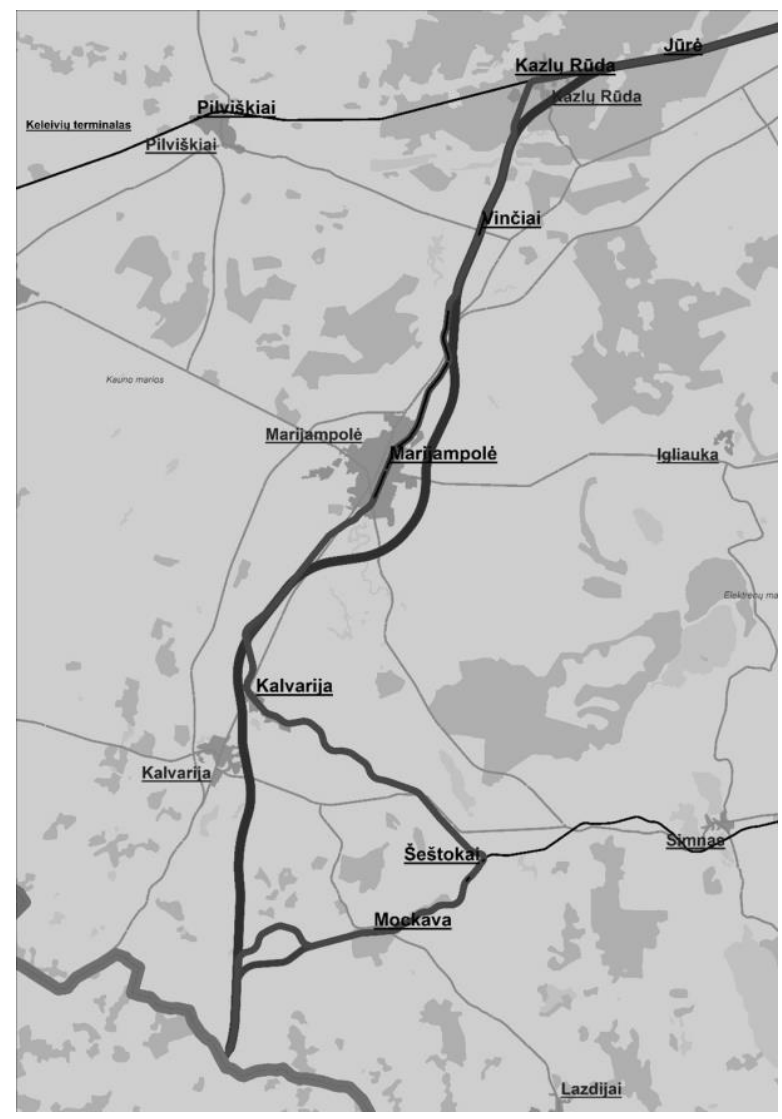

Figure 2. Polish/Lithuanian border - Kaunas railway line modernization alternative

It should be noted that during modernization works of existing $1435 \mathrm{~mm}$ gauge railway line in Lithuania, one of the main condition will be to do not close an existing traffic, the same condition will be applied in E75 Bialystok-ElkSuwalki railway line (Poland), which is foreseen to be modernized accordingly with the Rail Baltica main parameters as well.

\section{Rail Baltica design guidelines}

To avoid differences in design of railway infrastructure technical solutions between countries, which usually have different national legislation and practice, RBDG were created. It was agreed that "Rail Baltica" line shall accommodate passengers' trains classified as P2 traffic code and freight trains classified as F1 traffic code and gauge structure GC (agreed to update to SeC on 2020) will be applied (Figure 3). 


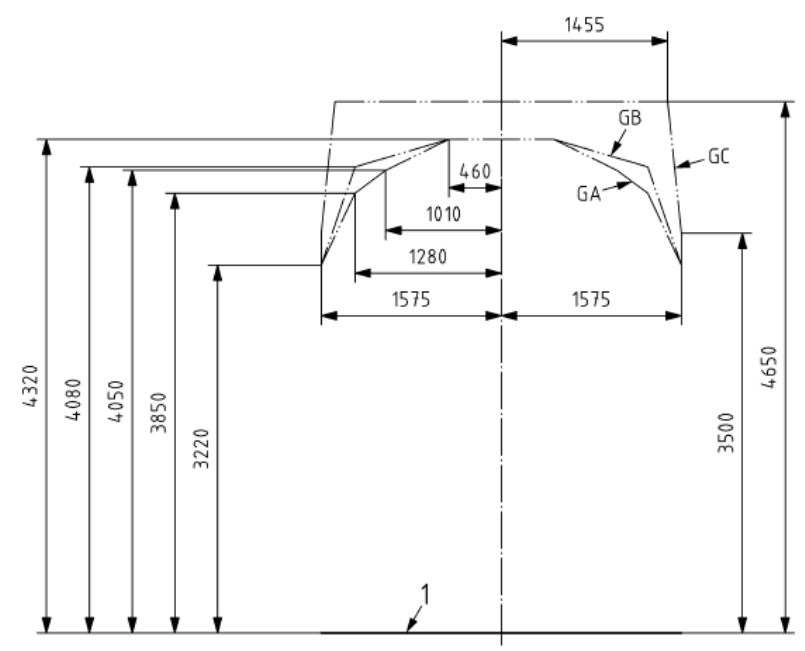

Figure 3. Reference profiles for static gauges GA, GB and GC

Main parameters and requirements were agreed to use for railway alignment, superstructure-track and substructure (embankments and earthworks, hydraulic, drainage and culverts, bridges, overpasses, tunnels and similar structures), railway energy (traction power system, catenary, non-traction power supply, electromagnetic compatibility), railway control-command signaling system, telecommunications system, SCADA, infrastructure facilities, stations and passenger platforms, environment, mechanical electrical plumbing in tunnel, adaption to climate change, BIM, architectural and landscaping, visual design requirements and security. Main line general cross-sections were prepared for designing (Figure 4).

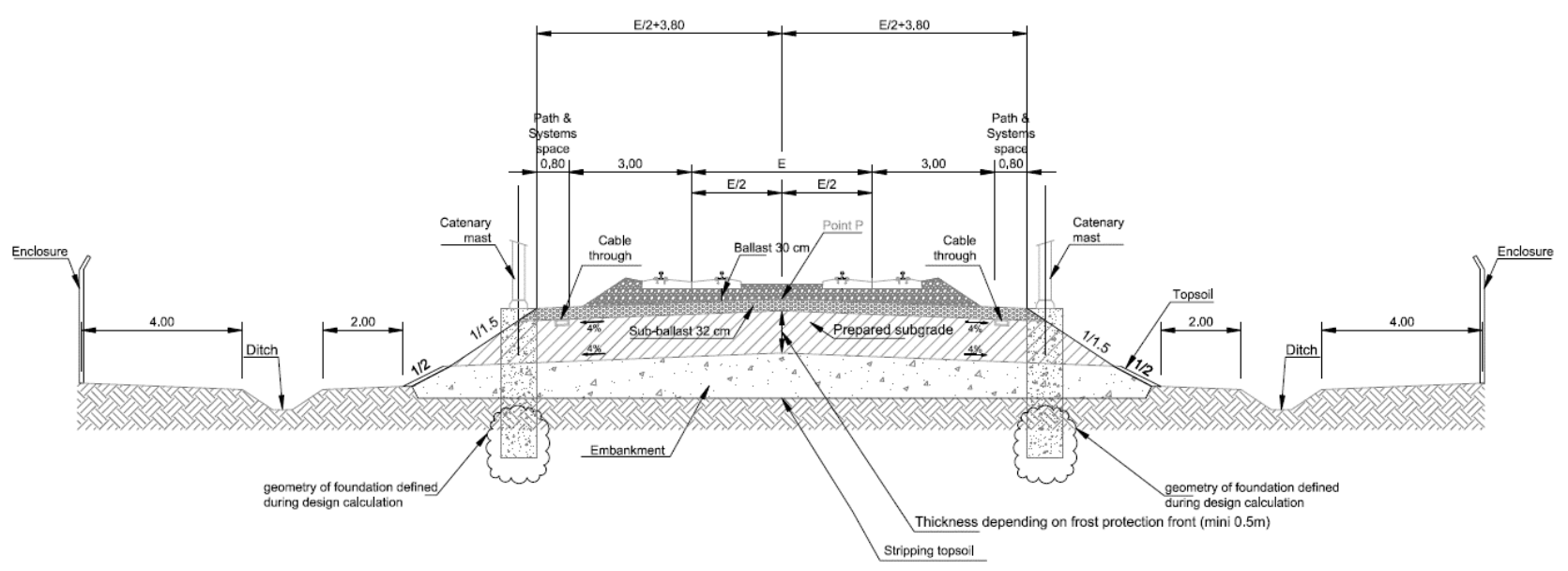

Figure 4. Cross-sectional profile. Main line embankment - Double track

\section{Expert survey methodology}

Expert survey methodology was applied for $1435 \mathrm{~mm}$ gauge railway infrastructure which is not in line with "Rail Baltica" main technical requirements and needs to be modernized accordingly. The aim of the survey was to rate main railway infrastructure technical parameters which should be used for railway modernization projects, when significant constraints exists. The survey evaluated in practice non-existent $1435 \mathrm{~mm}$ gauge railway line constructed by technical parameters: single track $1435 \mathrm{~mm}$ gauge railway line with passing loops, non-electrified, no ERTMS installed, passenger train design speed $-160 \mathrm{~km} / \mathrm{h}$, freight train design speed $-80 \mathrm{~km} / \mathrm{h}, 22.5 \mathrm{t}$ axle load, freight train length $750 \mathrm{~m}$, passenger train length $-200 \mathrm{~m}$.

Experts participated in the survey were asked to rank infrastructure technical parameters by indicating what parameters should be met if significant project constraints such as insufficient financial resources, time shortage for project preparation and implementation would exists. It was agreed to do note rate the parameters accordingly construction technologies sequences. 


\section{Determination of the weight criteria by Kendall method}

A criteria list was created prior to carrying out an expert survey. An existing scientific literature review was carried out to compile the list of criteria. It was indicated that the main targets of the infrastructure modernization are optimal infrastructure capacity (Gašparík et al., 2018), traffic safety level (Meijer et al., 2009), passenger and freight train speed (Lebid et al., 2019; Brezina \& Knoflacher, 2014; Ižvolt \& Hodas, 2012). It was noted as well that all main infrastructure parameters should be applied in a comprehensive system model to provide the optimum infrastructure design and capacity (Connor, 2014).

One of the main infrastructure parameters of the infrastructure is the geometry of the track (Lazarević et al., 2018a, 2018b; Stenstrom et al., 2012), on which not only the speed of the trains but also the energy consumption depends (Sarsembayev et al., 2015). When the railway traffic is increasing and with higher speed of trains there is an acute need for modernization of railway signalling technology. Even with the advent of microprocessor-based technology, the traffic capacity and safety targets could not be reached (Patalay, 2014).

The list below is made by way of expertise, i.e. a group, consisting of 11 persons formed by the authors hereof, have selected 20 key criteria (Table 1), which later should be subject to attribution of certain weights. 20 criteria for expert evaluation (Yazdani et al., 2016).

Table 1. Criteria list and description

\begin{tabular}{|c|c|c|}
\hline $\begin{array}{l}\text { Item } \\
\text { No. }\end{array}$ & $\begin{array}{l}\text { Railway infrastructure } \\
\text { technical parameter }\end{array}$ & Description \\
\hline Q1 & Structure gauge & $\begin{array}{l}\text { The structure gauge is the area where no track-side equipment shall be located (sig- } \\
\text { nals, catenary masts, etc.). It determines minimum height of structures tunnels and } \\
\text { bridges. It is considered for "Rail Baltica" project to use GC structure gauge (agreed to } \\
\text { update to } \mathrm{SeC} \text { on 2020) }\end{array}$ \\
\hline Q2 & $\begin{array}{l}\text { Distance between track } \\
\text { centres }\end{array}$ & $\begin{array}{l}\text { It is agreed that main lines in project "Rail Baltica" will be designed and constructed } \\
\text { as double track. Therefore, it is important to use proper horizontal distance between } \\
\text { track centers. According with INF TSI, when the design speed is from } 200 \mathrm{~km} / \mathrm{h} \text { up to } \\
250 \mathrm{~km} / \mathrm{h} \text { minimum nominal horizontal distance between track centres is } 4.0 \mathrm{~m} \text {, con- } \\
\text { sidering the margins for aerodynamic effects. However, according with RBDG, for } \\
\text { mixed traffic section with } 249 \mathrm{~km} / \mathrm{h} \text { maximum design speed it is agreed to use } 4.5 \mathrm{~m} \\
\text { minimum distance between track centres }\end{array}$ \\
\hline Q3 & Maximum gradients & $\begin{array}{l}\text { According with INF TSI, the gradient of tracks through passenger platforms and of } \\
\text { rolling stock parking tracks shall not be more than } 2.5 \mathrm{~mm} / \mathrm{m} \text {. The slope of the P1 } \\
\text { main lines shall be } 25 \mathrm{~mm} / \mathrm{m} \text {. An exception for slope of } 35 \mathrm{~mm} / \mathrm{m} \text { could be used for } \\
\text { the distances which do not exceed } 6 \mathrm{~km} \\
\text { However, according with RBDG, the maximum gradient of } 12.5 \mathrm{~mm} / \mathrm{m} \text { shall be used } \\
\text { for mixed lines. It is considered nominal gradient of } 8.0 \mathrm{~mm} / \mathrm{m} \text { for design of main } \\
\text { lines purposes. For passenger lines maximum gradient of } 25 \mathrm{~mm} / \mathrm{m} \text { can be used. For } \\
\text { station tracks the nominal gradient limit is } 0 \mathrm{~mm} / \mathrm{m} \text {. The maximum gradient limit is } \\
1.5 \mathrm{~m} / \mathrm{mm} \text { and the exceptional gradient limit is } 2.5 \mathrm{~mm} / \mathrm{m}\end{array}$ \\
\hline Q4 & $\begin{array}{l}\text { Minimum radius of hori- } \\
\text { zontal curve }\end{array}$ & $\begin{array}{l}\text { According with RBDG, minimum radius of horizontal curve is considered as } 3600 \mathrm{~m} \text {. } \\
\text { Recommended value is considered as } 4000 \mathrm{~m} \text {, when the design speed is } 249 \mathrm{~km} / \mathrm{h} \text { and } \\
\text { cant value is } 90 \mathrm{~mm}\end{array}$ \\
\hline Q5 & $\begin{array}{l}\text { Minimum radius of verti- } \\
\text { cal curve }\end{array}$ & $\begin{array}{l}\text { According with RBDG, recommended radius of vertical curve is considered as } 37201 \\
\mathrm{~m} \text {, exceptional value is } 21700 \mathrm{~m} \text { and minimum value is } 15500 \mathrm{~m} \text {, when design speed } \\
\text { is } 249 \mathrm{~km} / \mathrm{h}\end{array}$ \\
\hline Q6 & Number of tracks & It is agreed to use double track for main lines in "Rail Baltica" \\
\hline Q7 & Cant & $\begin{array}{l}\text { According to INF TSI, the design cant for ballasted track of freight and mixed traffic } \\
\text { lines shall be limited to } 160 \mathrm{~mm} \text {, for ballasted track of passenger traffic lines only } \\
\text { shall be limited to } 180 \mathrm{~mm} \\
\text { However, according to RBDG, the design cant shall be limited to } 90 \mathrm{~mm} \text { and the ex- } \\
\text { ceptional value is } 110 \mathrm{~mm}\end{array}$ \\
\hline Q8 & $\begin{array}{l}\text { Design geometry of } \\
\text { switches and crossings }\end{array}$ & $\begin{array}{l}\text { INF TSI does not foresee exact requirements for design geometry of switches and } \\
\text { crossings. However, it is indicated that the infrastructure manager needs to decide geo- } \\
\text { metrical design values appropriate to its maintenance plan } \\
\text { For "Rail Baltica" project it is recommended that mainline separation turnouts and } \\
\text { crossovers carrying fare paying passengers have a minimum operating speed in the di- } \\
\text { verging track } 140 \mathrm{~km} / \mathrm{h}\end{array}$ \\
\hline
\end{tabular}


End of Table 1

\begin{tabular}{|c|c|c|}
\hline $\begin{array}{l}\text { Item } \\
\text { No. }\end{array}$ & $\begin{array}{l}\text { Railway infrastructure } \\
\text { technical parameter }\end{array}$ & Description \\
\hline Q9 & $\begin{array}{l}\text { Track resistance to verti- } \\
\text { cal loads }\end{array}$ & $\begin{array}{l}\text { Track resistance to vertical loads considers the track, including switches and crossings } \\
\text { affecting forces: the axle load, maximum vertical wheel forces and vertical quasi-static } \\
\text { wheel forces }\end{array}$ \\
\hline Q10 & $\begin{array}{l}\text { Longitudinal track re- } \\
\text { sistance }\end{array}$ & $\begin{array}{l}\text { Longitudinal track resistance considers longitudinal forces equivalent to the force aris- } \\
\text { ing from braking of } 2.5 \mathrm{~m} / \mathrm{s}^{2}\end{array}$ \\
\hline Q11 & Lateral track resistance & Lateral track resistance considers lateral forces and quasi-static guiding forces \\
\hline Q12 & $\begin{array}{l}\text { Resistance of bridges to } \\
\text { traffic loads }\end{array}$ & $\begin{array}{l}\text { Resistance of bridges to traffic loads consists of vertical loads, allowance for dynamic } \\
\text { effects of vertical loads, centrifugal forces, nosing forces, actions due to traction and } \\
\text { braking (longitudinal loads) and design track twist due to rail traffic actions. RBDG } \\
\text { indicates to refer for requirements needed in INF TSI }\end{array}$ \\
\hline Q13 & $\begin{array}{l}\text { Resistance of new struc- } \\
\text { tures over or adjacent to } \\
\text { tracks }\end{array}$ & $\begin{array}{l}\text { Resistance of new structures over or adjacent to tracks is described as aerodynamic ac- } \\
\text { tions from passing trains. RBDG indicates to refer for requirements needed in INF TSI }\end{array}$ \\
\hline Q14 & $\begin{array}{l}\text { Resistance of new struc- } \\
\text { tures over or adjacent to } \\
\text { tracks }\end{array}$ & $\begin{array}{l}\text { Resistance of new structures over or adjacent to tracks considers bridges and earth- } \\
\text { works resistance interoperability according to the TSI category of line. RBDG indi- } \\
\text { cates to refer for requirements needed in INF TSI }\end{array}$ \\
\hline Q15 & $\begin{array}{l}\text { Usable length of freight } \\
\text { station tracks }\end{array}$ & $\begin{array}{l}\text { According to INF TSI, the usable length of freight station track varies from } 740 \text { up to } \\
1050 \mathrm{~m} \text {. However, according to RBDG, usable length of freight station track is } \\
1050 \mathrm{~m} \text { which shall allow to retain } 1050 \mathrm{~m} \text { long freight trains }\end{array}$ \\
\hline Q16 & $\begin{array}{l}\text { Usable length of passen- } \\
\text { ger station tracks }\end{array}$ & $\begin{array}{l}\text { According to INF TSI, the usable length of passenger station track varies from } 200 \text { up } \\
\text { to } 400 \mathrm{~m} \text {. However, according to RBDG, usable length of passenger station track is } \\
405 \mathrm{~m}\end{array}$ \\
\hline Q17 & $\begin{array}{l}\text { Usable length of plat- } \\
\text { forms }\end{array}$ & $\begin{array}{l}\text { According to INF TSI, the length of passenger station platform varies from } 200 \text { up to } \\
400 \mathrm{~m} \text {. However, according to RBDG, the length of passenger station platform is } \\
400 \mathrm{~m}\end{array}$ \\
\hline Q18 & Platform height & $\begin{array}{l}\text { According to INF TSI two values are allowed for platform height: } 550 \text { and } 760 \mathrm{~mm} \text {. } \\
\text { However, for Rail Baltica project } 550 \mathrm{~mm} \text { shall be used. A } 12 \text {-meter-wide is usually } \\
\text { planned on island platform and } 6 \text { to } 9 \text { meters on lateral platforms }\end{array}$ \\
\hline Q19 & Voltage and frequency & $25 \mathrm{kV} 50 \mathrm{~Hz}$ AC system is planned to be designed \\
\hline Q20 & $\begin{array}{l}\text { Railway traffic manage- } \\
\text { ment system }\end{array}$ & ERTMS level 2 for Rail Baltica project foreseen to be implemented and used \\
\hline
\end{tabular}

Individual surveys to these experts, hereinafter referred to as E1-E11, gave the results about the importance of criteria that can be observed in the Table 2 .

Table 2. Criteria ranks awarded by each expert

\begin{tabular}{|c|c|c|c|c|c|c|c|c|c|c|c|c|c|c|c|c|c|c|c|c|}
\hline & Q1 & Q2 & Q3 & Q4 & Q5 & Q6 & Q7 & Q8 & Q9 & Q10 & Q11 & Q12 & Q13 & Q14 & Q15 & Q16 & Q17 & Q18 & Q19 & Q20 \\
\hline E1 & 1 & 2 & 18 & 8 & 12 & 3 & 10 & 7 & 15 & 17 & 14 & 11 & 20 & 16 & 19 & 9 & 13 & 6 & 5 & 4 \\
\hline E2 & 1 & 5 & 6 & 15 & 10 & 14 & 16 & 17 & 4 & 9 & 18 & 2 & 11 & 3 & 20 & 19 & 13 & 12 & 7 & 8 \\
\hline E3 & 1 & 2 & 4 & 8 & 10 & 19 & 3 & 9 & 7 & 5 & 6 & 11 & 20 & 12 & 16 & 15 & 17 & 18 & 14 & 13 \\
\hline E4 & 12 & 9 & 8 & 7 & 6 & 5 & 4 & 3 & 20 & 19 & 18 & 17 & 16 & 15 & 14 & 1 & 13 & 2 & 11 & 10 \\
\hline $\mathbf{E 5}$ & 3 & 4 & 5 & 6 & 7 & 2 & 8 & 1 & 16 & 18 & 19 & 9 & 10 & 11 & 12 & 13 & 14 & 15 & 20 & 17 \\
\hline E6 & 3 & 4 & 14 & 15 & 16 & 12 & 13 & 5 & 9 & 10 & 11 & 7 & 8 & 1 & 20 & 19 & 18 & 17 & 6 & 2 \\
\hline E7 & 4 & 16 & 12 & 10 & 11 & 15 & 17 & 9 & 5 & 6 & 7 & 3 & 2 & 1 & 13 & 20 & 18 & 14 & 19 & 8 \\
\hline E8 & 5 & 6 & 14 & 15 & 18 & 4 & 19 & 13 & 10 & 11 & 12 & 2 & 9 & 3 & 7 & 8 & 16 & 17 & 20 & 1 \\
\hline E9 & 1 & 11 & 9 & 2 & 12 & 6 & 13 & 7 & 3 & 8 & 14 & 4 & 15 & 5 & 20 & 19 & 18 & 17 & 16 & 10 \\
\hline E10 & 1 & 2 & 12 & 11 & 13 & 19 & 14 & 9 & 6 & 7 & 8 & 3 & 4 & 5 & 17 & 18 & 20 & 15 & 16 & 10 \\
\hline E11 & 19 & 20 & 3 & 2 & 1 & 17 & 18 & 16 & 13 & 14 & 15 & 4 & 5 & 6 & 7 & 8 & 9 & 10 & 11 & 12 \\
\hline
\end{tabular}

One of the simplest methods applicable - Kendall method (Kendall, 1970). Ranking is done pursuant to the criteria list, i.e. when the highest rank is given by an expert to the most important criterion, i.e. place or score equal to one. The second most important criterion is given a rank equal to two, the third one - three and etc. The last rank receives the lowest value of ranking. This method is logical and easily applicable in practical calculations (Jakimavičius et al., 2016). 
Kendall concordance coefficient (Kendall, 1970) is linked with the sum of rank of each factor $R_{j}$ and with regard to respondents or experts:

$$
R_{j}=\sum_{i=1}^{n} R_{i j} . \quad(j=1,2, \ldots, m)
$$

The mean rank of each factor $\bar{R}$ is obtained dividing the sum of ranks assigned thereto by number of factors:

$$
\bar{R}=\frac{\sum_{j=1}^{m} R_{j}}{m}
$$

where: $R_{i j}$ - rank given by expert $i$ to factor $j ; n$ - number of experts $(i=1,2, \ldots, n) ; m$ - number of factors $(j=1,2$, $\ldots, m)$.

The difference between sum $\sum_{i=1}^{n} R_{i j}$ of ranks $R_{i j}$ and constant quantity $\frac{1}{2} n(m+1)$ is calculated for each criterion:

$$
\sum_{i=1}^{n} R_{i j}-\frac{n(m+1)}{2}
$$

The square of the difference between ranks' sum $\sum_{i=1}^{n} R_{i j}$ and constant quantity $\frac{n(m+1)}{2}$ is calculated:

$$
\left[\sum_{i=1}^{n} R_{i j}-\frac{1}{2} n(m+1)\right]^{2}
$$

Upon calculation as per formulas (1)-(4), the next step is to calculate the concordance coefficient $W$ :

$$
W=\frac{12 S}{n^{2}\left(m^{3}-m\right)} .
$$

Significance of concordance coefficient and compatibility of expert evaluation of factor groups is determined by $\chi^{2}$ :

$$
\chi^{2}=\frac{12 S}{n m(m+1)} .
$$

Min value of the concordance coefficient $W_{\min }$ is calculated from formula (7):

$$
W_{\min }=\frac{\chi_{v, \alpha}^{2}}{n(m-1)},
$$

where: $\chi_{v, \alpha}^{2}$ - Pearson critical statistics, which value is found in the table (Montgomery, 2009), taking the degree of freedom $v=m-1$ and significance level $\alpha$.

The outcome from 11 expert surveys was that the structure gauge should be firstly adjusted (0.0779), second place - resistance of bridges to traffic loads (0.0684), third place - resistance of earthworks to traffic loads (0.0662), fourth place - distance between track centres (0.064), fifth place - railway traffic management system (0.0589), other criteria weights of modernization of $1435 \mathrm{~mm}$ gauge railway infrastructure are provided in Figure 5.

According to the results achieved, the priority parameters, were identified for railway modernization projects, when significant constraints exists such as insufficient financial resources. It should be noted that:

First priority parameters are structure gauge, resistance of bridges to loads and resistance of new structures over or adjacent to tracks. This parameters group could be explained as basic parameters which should be met prior to any railway traffic operation. For an instance, the structure gauge will play the most important role in the route consideration between different infrastructure managers. As well as resistance of bridges to loads and resistance of new structures over or adjacent to tracks will have crucial importance in route consideration and traffic safety.

Second priority parameters are distance between track centres, railway traffic management system, design geometry of switches and crossings. This parameters group could be assigned to the parameters which have biggest influence on the railway infrastructure performance - traffic speed, safety and management. 


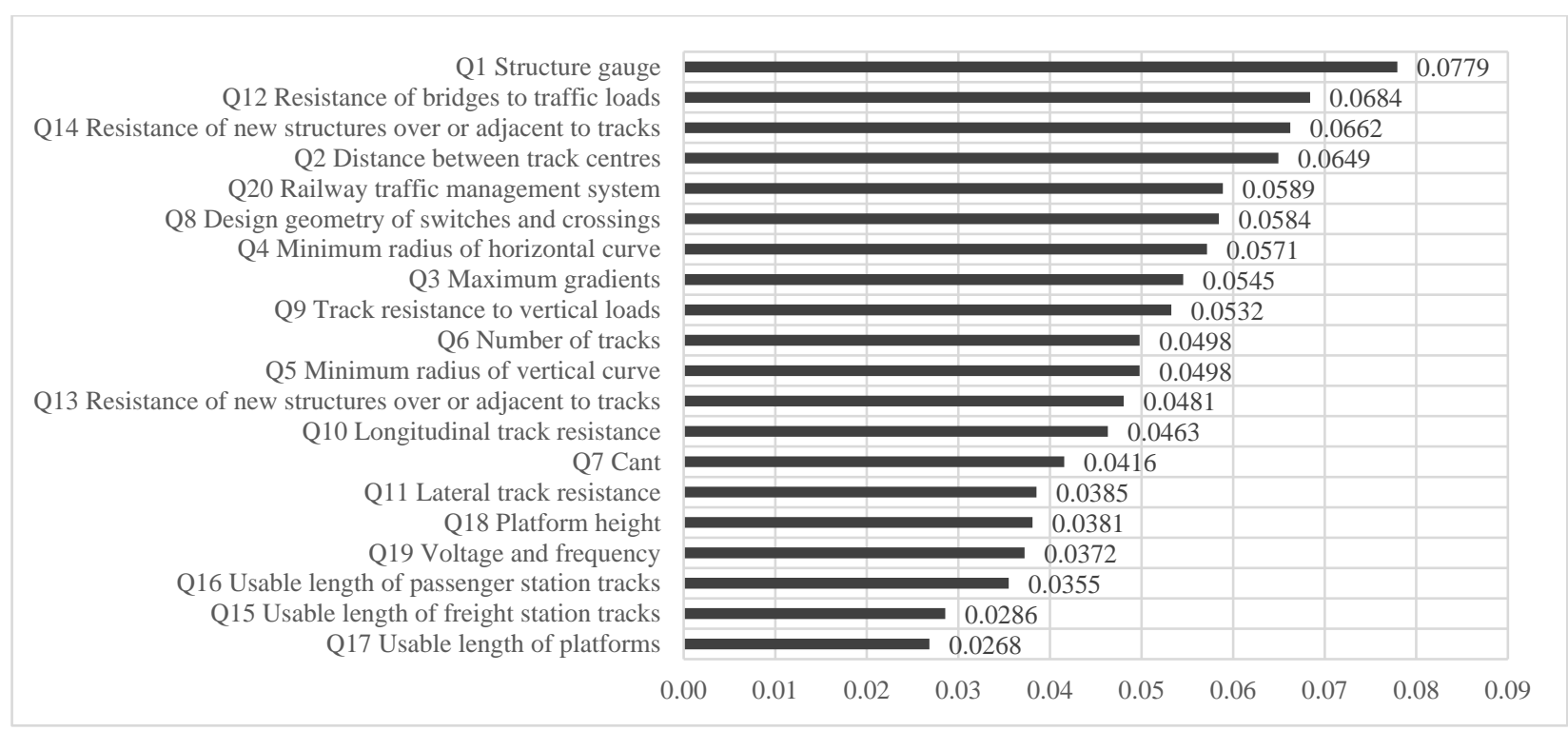

Figure 5. Determined criteria weights

Third priority parameters are minimum radius of horizontal curve, maximum gradients and track resistance to vertical loads, which corresponds mostly railway infrastructure operational parameters - traffic speed, safety, energy consumption and maximum loads of freight trains.

Fourth priority parameters are all other subsequent parameters, which are similar in purpose to parameters mentioned upon, but according to the survey results have lower importance. Additionally, should be discussed usable length of freight station tracks, passenger station tracks and passenger platforms. It should be stated that these parameters have crucial importance for railway infrastructure performance, effectiveness.

\section{Conclusions}

It should be noted at first that expert survey was conducted for a project which does not exist in the practice. Construction technologies and their sequence were not considered. Some expert surveys circumstances and conditions were taken from similar long-term international importance projects such as "Rail Baltica" project practice achieved during 2008-2015 years period, when insufficient project implementation time constraint existing as well as lack of commonly agreed technical parameters for project development between project partners.

After the expert surveying and evaluation of weights of railway infrastructure parameters it has been determined the basic parameters which need to be met during modernization of the projects when insufficient financial resources and time shortage for project preparation and implementation exist. Such parameters are prioritized as fallows: first place - structure gauge (0.0779), second place - resistance of bridges to traffic loads (0.0684), third place - resistance of earthworks to traffic loads (0.0662), fourth place - distance between track centres $(0.064)$ and fifth place - railway traffic management system (0.0589).

It should be noted that similar expert survey should be conducted within the normal conditions when any constraints does not exist. It is obvious that according such conditions modernization parameters theoretically would be prioritized as follows: structure gauge, track alignment (horizontal and vertical radiuses, cant, distance between track centers, maximum gradients), number of tracks, design geometry of switches and crossings, track and bridge resistance to traffic loads, usable length of station tracks and platforms.

Therefore, for every railway infrastructure modernization project should be identified clear targets which shall be reached, constraints which exist and only afterwards - main infrastructure parameters that should be modernized. Using such framework, a comprehensive system model should be created and further research should be done.

\section{References}

Brezina, T., \& Knoflacher, H. (2014). Railway trip speeds and areal coverage. The emperor's new clothes of effectivity? Journal of Transport Geography, 39, 121-130. https://doi.org/10.1016/j.jtrangeo.2014.06.024

Connor, P. (2014). High speed railway capacity. Understanding the factors affecting capacity limits for a high speed railway (pp. 1-9). https://www.semanticscholar.org/paper/High-Speed-Railway-Capacity-Understanding-the-for-aConnor/c9caf4be3568723233725113c43b2a58f13cf870 
European Union. (2004). Decision No 884/2004/EC of the European Parliament and of the Council of 29 April 2004 amending Decision No 1692/96/EC on Community guidelines for the development of the trans-European transport network. https://eur-lex.europa.eu/legal-content/EN/TXT/?uri=CELEX:32004D0884

Gašparík, O., Abramović, B., \& Zitrický, V. (2018). Research on dependences of railway infrastructure capacity. Tehnicki Vjesnik, 25(4), 1190-1195. https://doi.org/10.17559/TV-20160917192247

Han, S. H., Yun, S., Kim, H., Kwak, Y. H., Park, H. K., \& Lee, S. H. (2009). Analyzing schedule delay of mega project: Lessons learned from Korea train express. IEEE Transactions on Engineering Management, 56(2), 243-256.

Ižvolt, L., \& Hodas, S. (2012). Modernisation of railway infrastructure in the Slovak Republic. Computers in Railways XIII, 211223. https://doi.org/10.2495/CR120191

Jakimavičius, M., Burinskienè, M., Gusarovienė, M., \& Podviezko, A. (2016). Assessing multiple criteria for rapid bus routes in the public transport system in Vilnius. Public Transport, 8(3), 365-385. https://doi.org/10.1007/s12469-016-0146-7

Kendall, J. M. (1970). The turbulent boundary layer over a wall with progressive surface waves. Journal of Fluid Mechanics, 41(2), 259-281. https://doi.org/10.1017/S0022112070000617

Lazarević, L., Popović, Z., Vilotijević, M., \& Mirković, N. (2018a). Interoperability of railway infrastructure in the republic of Serbia. In International Scientific Conference Energy Management of Municipal Facilities and Sustainable Energy Technologies EMMFT 2018 (pp. 281-289). https://doi.org/10.1007/978-3-030-19756-8_25

Lazarević, L., Popović, Z., Vilotijević, M., \& Mirković, N. (2018b). Track alignment parameters on modern railway lines for mixed traffic. Paper presented at the Conference: XVIII International Scientific-Expert Conference on Railways - RAILCON 2018.

Lebid, I., Kravchenya, I., Dubrovskaya, T., Luzhanska, N., Berezovyi, M., \& Demchenko, Y. (2019). Identification of the railway reconstruction parameters at imposition of high speed traffic on the existing lines. MATEC Web of Conferences, 294(7), 05003. https://doi.org/10.1051/matecconf/201929405003

Meijer, S., Kracht, P., Luipen, J., \& Schaafsma, A. (2009). Studying a control concept for high-frequency train transport. Paper presented at the $20092^{\text {nd }}$ International Conference on Infrastructure Systems and Services: Developing $21^{\text {st }}$ Century Infrastructure Networks (INFRA). https://doi.org/10.1109/INFRA.2009.5397864

Montgomery, D. C. (2009). Design and analysis of experiments $\left(7^{\text {th }}\right.$ ed.). John Wiley \& Sons, Inc.

Patalay, S. (2014). Analysis of railway interlocking systems (pp. 1-23).

Sarsembayev, B., Suleimenov, T., \& Arpabekov, M. (2015). Analyze of impact of track alignment on the energy consumption level. International Journal of Traffic and Transportation Engineering, 4(2), 45-49.

Stenstrom, C., Parida, A., \& Galar, D. (2012). Performance indicators of railway infrastructure. International Journal of Railway Technology, 1(3). https://doi.org/10.4203/ijrt.1.3.1

Yazdani, M., Zavadskas, E. K., Ignatius, J., \& Doval Abad, M. (2016). Sensitivity analysis in MADM methods: application of material selection. Engineering Economics, 27(4), 382-391. https://doi.org/10.5755/j01.ee.27.4.14005 